\title{
MEANING AND SCOPE OF SOCIAL ANTHROPOLOGY
}

\section{By Prof. A. R. RADCLIFFE-BROWN University of Oxford}

$\mathrm{T}_{\mathrm{H}}^{\mathrm{H}}$ HE name 'social anthropology' came into use some sixty years ago to distinguish the subject from ethnology. The avowed aim has always been to apply the inductive method of the natural sciences to the study of human society, its institutions and its evolution. But it is only gradually that we can learn how to apply the inductive method in a new field. The history of chemistry from the time of Bacon to Lavoisier illustrates this. So social anthropology is not now what it was in 1890. At that time theoretical discussions in social anthropology were largely concerned with speculations about origins (of religion, of totemism, of exogamy, etc.). There are still some social anthropologists who remain faithful to the ideas and methods of 1890. But the work now being done in the subject consists largely of experimental studies, combining observation and analysis, of particular social systemas, intended to provide material for the systematic comparison of systems of different types and to test existing hypothetical conceptions. Anyone who wants to know what social anthropology is doing at the present day should read the admirable work of Arensberg and Kimball on "Family and Community in Ireland".

One of the most completely organized departments of anthropology is that of the University of Chicago. The subject is divided into five fields: physical anthropology, archæology, ethnology, linguistics and social anthropology. Students, who must already have the degree of B.A. before entering the department, are required to devote a period of study to all five subjects and pass a comprehensive examination in all of them. Thereafter the student specializes in one of the fields for his degree of Ph.D. A brilliant student can complete this work in four years, but many take longer.

We may consider this combination of subjects from the point of view of each one of them in turn. Physical anthropology proper, as distinct from human biology, is the study of variation in the human family (the Hominidæ) and of human evolution. It includes, therefore, not only the study of existing varieties of Homo sapiens, but also human and primate palæontology. A student who aims at being a competent physical anthropologist must first obtain a thorough grounding in biology, comparative morphology (particularly of the primates), human anatomy, histology, embryology and physiology. It seems desirable that he should have some acquaintance with archæology and ethnology. His own special work will in no way be helped by any study of linguistics or social anthropology.

Ethnology, as the name shows, is the study of 'peoples'. Peoples, or ethnic groups, differ from and resemble one another in racial character, in language and in culture. The ethnologist compares and classifies peoples on the bases of these similarities and differences, so that he has to deal with racial, linguistic and cultural classifications. Further, he seeks to discover by various methods something about migrations, interactions and developments of peoples in the past.

It is evident that the competent ethnologist should possess a sound knowledge of physical anthropology, linguistics and social anthropology. Ethnological literature is very heavily overloaded with uncritical speculations. A writer who talks glibly of brachycephaly and dolichocephaly but is completely ignorant of the complexities of structure of the skull will offer us an account of the movements and developments of races from the first appearance of man. One who is ignorant of linguistic science will affirm a connexion of two widely separated languages on the evidence of similarities of a few words selected from imperfect vocabularies. Or one who, by his lack of knowledge of social anthropology, is ignorant of the nature of institutions such as totemism or exogamous moieties, will affirm that these institutions all over the world must have been introduced by Egyptians looking for gold, pearls and cowrie shells.

Prehistoric archæology is really one kind of ethnology (palæo-ethnology), the study of the peoples of the prehistoric past who are known to us only from their remains-their dwelling sites, their bones, the implements they made and used. Since the archæologist recovers no traces of the languages or the social institutions of these vanished peoples he has no need, in the pursuance of his own special studies, for any knowledge of linguistics or social anthropology. On the other hand, he has to know something of geology and surveying. It would seem to be most desirable that ethnology and archæology should keep closely together. They are merely branches of a single study.

Linguistics, the systematic study of language in general, as distinguished from the study of particular languages or groups of languages, is regarded in the United States as one of the fields of anthropology. In England the subject, as a subject, has not yet received recognition except in the School of Oriental Studies, London. A student who intends to specialize in linguistics does not really need to know anything more about physical anthropology or prehistoric archæology than ought to be known by every educated person. But there are important connexions of linguistics with ethnology and social anthropology. For example, the ethnological problem of the Aryan people is a linguistic problem as well as an archæological, racial and cultural problem.

We come finally to social anthropology-the general theoretical study of social institutions-law, religion, political and economic organization, ete. Within his own field of study, the social anthropologist has no use for physical anthropology. If it should ever be proved that racial (that is, biologically inherited) characters influence social institutions or their development, then he would take due note of the fact.

Prehistoric archæology obviously makes no contribution to such branches of social anthropology as comparative religion, the comparative study of law or of kinship or of economic systems. It does not even provide very much help to the study of comparative technology as that is conducted in social anthropology, where what is sought is to determine the mutual interrelations between the system of techniques and the other parts of the total social system. Certainly a social anthropologist should be acquainted with the general results of prehistoric archæology, but the methods of the archæologist and the details of investigation are not his concern as a social anthropologist.

There is often a good deal of confusion about the relation of social anthropology to ethnology. To a certain extent, but only to a certain extent, they deal 
with the same facts. But they deal with them in quite different ways. A typical problem of ethnology is how and when the ancestors of the American Indians entered the continent of America and how they developed the differences of racial character, language and culture which they exhibited when Europeans first came in contact with them. A typical problem of social anthropology is, "What is the nature of Law ?" An ethnologist and a social anthropologist might both study the same American Indian tribe, but one would be looking for facts relevant to his aim of placing the tribe within his general picture of the peoples of the continent; the other would be examining the way in which the tribe deals with infractions of custom in its bearing on a general theory of the nature and function of law.

Since both ethnology and social anthropology need field studies, there is an obvious economy of labour if a field worker can provide the material needed by the ethnologist and also that needed by the social anthropologist. In some field studies this has been done. But a field study in social anthropology needs more than description; it requires theoretical analysis. There are innumerable examples of ethnographic monographs which are admirable for the purposes of ethnology but are extremely unsatisfactory to the social anthropologist who might wish to make use of the data.

Ethnographical field studies are generally confined to the pre-literate peoples. In the last ten years, field studies by social anthropologists have been carried out on a town in Massachusetts, a town in Mississippi, a French Canadian community, County Clare in Ireland, villages in Japan and China. Such studies of communities in 'civilized' countries, carried out by trained investigators, will play an increasingly large part in the social anthropology of the future.

It is now possible to see that what holds the various branches of anthropology together is the central position of ethnology (with archæology) as the geographical, historical and classificatory study of races and peoples, past and present. It is for this reason that ethnology and anthropology are sometimes regarded as being one and the same. It is an interesting fact that the symposium (as it is now commonly called) on the future of anthropology at the centenary meeting of the Royal Anthropological Institute included discussions on physical anthropology, archæology, social anthropology and the study of material culture. There was no one to speak on the future of ethnology. Ethnology takes contributions from physical anthropology and linguistics, but gives little to them in return. Social anthropology as the study of evolution is in bad odour with some ethnologists at present, so that while they give little they also take little.

But what of the relations of the branches of anthropology to subjects that lie outside the field of anthropology? Physical anthropology has its closest connexion with the biological sciences. There is a tendency to seek to absorb it into a wider study of human biology, which would, presumably, also include what is called social biology. The study of the Bantu languages or the languages of the American Indians is left to the anthropologist, but not the study of the Indo-European and Semitic languages. How (and why) draw a line between prehistoric archæology and the archæology of historic times ? But if no such line is drawn, archæology becomes continuous with history. Ethnology, or some part of it, is claimed as a subdivision of geography-ethnogeography. And where, at the present time, are we to put anthropogeography or human geography, in geography or in anthropology or in both ?

Ethnology deals with the history of peoples. But the rest of history is excluded from anthropology. Yet the closest connexion of social anthropology is with the history of institutions-economic history, the history of religion, of law, of political organization, of science, etc. But to the social anthropologist the history of Europe or of Christianity is of no more interest than the history of India or China, of Islam or Buddhism.

The writer of the article on "The Future of Anthropology" (see Nature, Nov. 20, 1943, p. 587), which surveyed the discussion at the centenary meeting of the Royal Anthropological Institute, asks, 'Who is to study the world-wide history and development of social institutions?" The answer is, in the first place, the historians. The social anthropologist cannot examine for himself the original sources for the economic, political, legal and religious history of ancient Greece and Rome, India, China, Russia, Persia and Turkey. It is unusual for him to be thoroughly competent in even one of these fields. The social anthropologist, for the most part, has to take the facts about institutional history and develop. ment from the historians, though, of course, he has to exercise his judgment as to the reliability of a particular historian. What the social anthropologist does with this material is to use it to formulate his general hypotheses about law, religion, economic organization and so on. But these hypotheses need to be verified; and although some verification is possible by the comparison of different historical societies, the final test lies in actual (experimental) observation of existing social systems.

Political systems, economic systems, and systems of law are studied in social anthropology and also in economics, political science and jurisprudence. But there are very important differences of method. One of these, though by no means the most important, is that in the three studies mentioned attention is usually confined to certain types of society, whereas social anthropology has for its field all human societies and therefore tends to pay most attention to those which are neglected by the social sciences. It is true that at present there is no close connexion of the three social sciences with social anthropology, but this may be expected to develop as the lastnamed subject itself develops.

As anthropology is at present recognized, psychology lies outside. Yet social anthropology stands in a very close relation to psychology. To make the relationship clear it is necessary to distinguish between two kinds of psychology. Psychology is here taken to mean the study of the mental or psychic systems-if you will, the behaviour systems-of organisms. We may study the behaviour, the external manifestations of the psyche, of earthworms, rats or chimpanzees. General human psychology deals with the mental characteristics which are possessed by all human beings. Social anthropology deals with the characteristics of all human social systems. A social system consists of a certain set of social relations between certain human beings, exhibited to observation in their interactions with one another. It is obvious that one determining factor in the formation of human social systems is that basic human nature which it is the business of the general psychologist to study. Similarly, the nature of multicellular organisms is determined by the nature 
of the living cell which it is the business of the cytologist, the biochemist and the biophysicist to study. The connexion between social anthropology and general psychology is just as close and of just the same kind as the relation between animal physiology and cytology.

There are also what may conveniently be called 'special psychologies'. These deal, not with the universal characteristics of human beings, with basic human nature, but with the special mental or behaviour characteristics of individuals, types, classes or groups. Psychiatry affords an example of a 'special psychology', as do attempts to define psychological 'types'-extrovert, introvert; schizophrenic, cyclothymic ; pycnic, asthenic.

One of the 'special psychologies' consists of the study of the psychical characteristics (that is, characteristics of mind or behaviour) of the members of a defined social group, either a local community or a defined social class within a local community. When we study the 'psychology' of the French or the Germans or the people of the United States, we are dealing with those characteristics of mind or behaviour that result from 'conditioning' by a particular social system. Here the 'special' characteristics with which we are concerned are determined by the social system, while the social system itself is determined by the general characteristics of basic human nature.

It should be evident that there is a two-way connexion between social anthropology and psychology. Human societies are what they are because human beings are what they are. Similarly a human body is what it is because living cells are what they are. But why human beings belonging to a particular society or group exhibit certain characteristic modes of behaviour is because they have been 'conditioned', as the phrase is, by that society. Similarly the cells of a muscle act and react as they do because they are individual members of the muscle.

Prof. F. C. Bartlett (Nature, Dec. 18, 1943, p. 700) proposes drastic changes. $\mathrm{He}$ would give no place in anthropology to archrology, to linguistics (the general study of language), to ethnology (the geographical and historical study of races and peoples), or to social anthropology (as the comparative study of the forms of association found among human beings or as the study of social evolution). He would retain physical anthropology or anthropometry if it would abandon its present aim of studying evolution, variation and heredity in the human family and would devote itself to measuring physical characters that are correlated with differences of behaviour. He would also admit the study of material culture so long as it was limited to the study of the applications of natural knowledge and their influence on behaviour: $\mathrm{He}$ adds two other disciplines. One is the study of the effects of general environmental conditions on behaviour. The other is the study of "a group's psychological possessions, its traditions, beliefs, customs, ideals and of their repercussion upon social conduct". For Prof. Bartlett, anthropology should become a group of special psychologies dealing with the effects on behaviour of anatomical characters, environment, knowledge and the 'psychological possessions' of groups. Anthropologists need not fear, however, that Prof. Bartlett's drastic reforms will be carried out in the near future. Meanwhile, that 'special psychology' which is concerned with the way in which the behaviour of individuals is determined by the 'culture' of the society in which they live is already part of social anthropology.
But to say that it should be the whole of it is to deny to social anthropology the right to that study of the nature of social systems and of their evolution which is the raison d'être of the science.

Applied social anthropology is not much more than twenty years old. It was developed in South Africa, England and Australia in connexion with problems of Colonial administration. About twelve years ago it secured, despite the opposition of some ethnologists, a footing in the United States, not only in the Indian Bureau but also in the Soil Conservation Bureau and in an investigation of factory efficiency carried out in a large factory under the direction of Prof. Elton Mayo of Harvard. Since the United States came into the War, large numbers of anthropologists have teen called to Washington to carry out work which either is, or is supposed to be, applied anthropology.

There is a good deal of misunderstanding atout applied anthropology, what it is, what it can do and what it cannot do, but that matter obviously cannot be discussed here. The recognition of applied social anthropology has certain very definite advantages and certain equally definite disadvanteges. To mention only one of the latter, theoretical social anthropology is still in the formative stage. The demand on social anthropologists to spend too much of their time on practical problems would inevitably reduce the amount of work that can be given to the development of the theoretical side of the science. But without a sound basis in theory, applied anthropology must deteriorate and become not applied science but merely empirical practice.

What of the future,? Social anthropology must claim a position of relative independence. (There are already chairs of social anthropology at Oxford and Cambridge.) This does not mean that it should sever its connexion with ethnology, with which it has always been associated; and its connexion' with ethnology connects it indirectly with prehistoric archæology. It should maintain a close connexion with general linguistics, for language is a social institution. (At Oxford the only lectures on generel linguisties have been those given in the Institute of Social Anthropology.) It could maintain a closer connexion with human biology than with the narrower subject of physical anthropology.

Outside the field of what is called anthropology, it must maintain or establish connexions with psychology, with history (more particularly economic history, the history of law, of political organization, of religion) and with economics, political science and jurisprudence. The history of culture, in the sense of the history of art, of music, of literature, ought not to be neglected in any complete social anthropology, nor, of course, technological history. In the training of a social authropologist the first essential is a real understanding of the experimental method in seientific investigation, and this is best acquired by a thorough study of the history of science.

One part of social anthropology is the comparative study of economic systems. Surely there ought to be close connexion between this study and economics and economic history. Another part of sociel anthropology is the comparative study of legal systems, which demands a similar connexion with jurisprudence and the history of law; and so on with other parts of social anthropology. But whet part of social anthropology would give a similar close connexion with the study of the somatic differences exhibited by the various races of mankind, or with the study of the date and the affinities of the Solutrean 
or Capsian culture? So long as ethnology continues to exist, it will provide a meeting-ground for archæologists, physical anthropologists, students of linguistics, and social anthropologists. Such a meetingground has been provided for a century by the Royal Anthropological Institute and will continue to be provided in the future. Any attempt to impose a more rigid artificial unity will be likely to produce exactly the opposite of the result at which it aims.

\section{GENETICS AND KARYOLOGY OF DROSOPHILA SUBOBSCURA}

BY DR. U. PHILIP, J. M. RENDEL, H. SPURWAY and Prof. J. B. S. HALDANE, F.R.S.

$\mathrm{M}$ ODERN genetical theory is largely based on the study of Drosophila melanogaster, which has proved a useful guide to the genetics of other organisms. But there has been a tendency to regard this species as a standard, and any deviations from its genetical behaviour as exceptions.

The genetical study of other species of Drosophila has not merely opened a promising field of comparative genetics; it has also demonstrated that most species show qualitatively novel features. Thus $D$. virilis has a number of labile genes, $D$. miranda has two $X$-chromosomes. In $D$. ananassoe the males are triploid for at least one gene. D. pseudo-obscura $\mathrm{A}$, though apparently monotypic, is polymorphic for a number of intra-chromosomal gene orders, each with its characteristic geographical range; and $D$. subobscura has been found to be a structural heterozygote in both sexes. In general the comparison of species suggests that they differ at least as much in the arrangement and proportions of the gene material as with regard to genes themselves.

C. Gordon ${ }^{1}$ began the genetical study of Drosophila subobscura, and we owe some of our stocks to him. The study was continued by Gordon, Spurway, and Street $^{2}$ and Christie ${ }^{3}$, and we hope shortly to publish a series of papers on it. The species belongs to the obscura group of the subgenus Sophophora (Sturtevant ${ }^{4}$, and its diagnostic characters are given by Gordon (1936) according to Collin (unpublished). It appears to be a native British species, and seems to have a wide distribution in Europe. For in a letter sent just before the outbreak of war with Italy, Buzzati-Traverso and Pomini, of the University of Pavia, informed us that flies of our stocks had given hybrids with flies of a species found in Italy and Germany, on which they had made genetical and cytological studies. Its possible identity with Sokolov and Dubinin's ${ }^{5}$ D. obscura-3 from the U.S.S.R., is discussed later. The flies can be caught fairly regularly under 'bleeding' elms and oaks. We know little of the several related British species, and have so far not attempted to study their systematics.

At mitotic metaphase there are five pairs of telomitic rod-shaped chromosomes, and one pair of 'dots'. The $X$ - and $Y$-chromosomes, which are of equal length, are the longest pair of rods. They can also be distinguished from autosomes in that somatic pairing only occurs at their proximal ends.

The salivary gland nuclei contain one short and five long elements. The $Y$-chromosome is exceptional in including at least 15 euchromatic bands, which have homologues in the $X$. One of the autosomes carries a large swelling similar to the 'Balbiani Ring' of Chironomus. The long chromosomes contain a good deal of heterochromatin. In all other Drosophila species so far described, except $D$. busckii, the heterochromatin of the proximal ends of the chromosomes forms a large darkly staining chromocentre. In D. subobscura this heterochromatin consists of large pale granules, and there is no chromocentre (Emmens ${ }^{6}$ ).

The most interesting feature of the species is the polymorphism of the chromosomes, each of which presumably represents one element in Muller' ${ }^{7}$ terminology. Almost all larvæ both from wild parents and laboratory eultures show inversion configurations in one to five of the long chromosomes; no translocations have been found. The different chromosomal orders fall into two groups.

(a) Both homozygous forms seem as viable and fertile as the heterozygote. In the four cases of this type so far studied, one order is by far the commoner, and may be taken as the standard, from which the other orders may be said to differ by one or more inversions.

(b) In three cases the heterozygote appears to be more viable and fertile than either homozygote. Most larvæ show salivary configurations proving that in at least two of the paired autosomes the homologues differ in respect of a compound inversion. These inversions are an included inversion covering the middle third of one autosome, two adjacent inversions covering three fifths of another, and a pair of overlapping inversions covering the distal quarter of a third autosome. Thus three of the autosomes have two (if not more) equally common isomeric orders. As they differ in respect of compound inversions, these should reduce crossing-over in heterozygotes very efficiently.

From a cross between two structural heterozygotes, or between a heterozygote and a homozygote, we should expect equal numbers of larvæ homozygous and heterozygous for a particular chromosome. In fact, there are significantly fewer homozygotes, though the nature of the selection against them is so far unknown. Its efficiency may be judged from the fact that a line which, before inbreeding, was heterozygous for the three inversions the heterozygosity of which is favoured by selection, is still heterozygous for all of them after fifteen generations of brothersister mating. This would only be expected in one of 37,000 such lines in the absence of selection. Another similar stock was still heterozygous for all three after ten generations of brother-sister mating; after nineteen generations it was still heterozygous for one, and died out during the twenty-first. Stocks made cytologically homozygous for any two of the three orders tend to die out; however, we have one cytologically homozygous stock derived from a fertilized wild female; but this is extremely difficult to keep alive, though it can easily be crossed with our other stocks.

Thus the species resembles a permanent structural heterozygote such as many Oenothera species, though structural homozygotes are not quite inviable. Sokolov and Dubinin (loc. cit.) reported a similar structural heterozygosity in a species from Ukraine and Caucasia which they referred to as Drosophila obscura-3 without giving diagnostic characters. The detailed structure of the inversions seems to be different, and it will be of great interest to determine how close systematically their populations are to ours.

In some vertebrate species, such as mice, pure lines can easily be established. In others, brother- 